\title{
Mobility, cohabitation and cultural exchange in the lodging houses of early modern Venice
}

\author{
ROSA SALZBERG* \\ C/- Department of History, University of Warwick, Coventry, CV4 7AL, UK
}

\begin{abstract}
This article examines the thriving lodging house sector in early modern Venice, arguing that such spaces of temporary accommodation offer a valuable key to understanding how mobility and migration shaped the daily lived experience of the city. Lodging houses were important both to the many Venetian residents who profited from renting out rooms, and to the people who stayed in them, and found there companionship, conversation and access to social and professional networks. Considering the kinds of encounters, conflicts and exchanges that unfolded in these shared spaces, the article offers new insight into the functioning of a premodern multicultural metropolis.
\end{abstract}

In the 1580s, the Venetian Inquisition examined the inhabitants of one of the city's many lodging houses. Located in a small courtyard in a densely populated area about ten minutes walk east of the central Piazza San Marco, the house was run by a Venetian woman, Paolina Briani, who made her living renting rooms to Greek and Ottoman Muslim merchants who came to trade in the great entrepôt city. Although the Venetian government was keen to promote this kind of economic exchange, fundamental to the wealth of their Republic, local authorities both secular and religious also were concerned about the sociable encounters that it engendered. In particular, the Inquisition was moved to investigate reports of promiscuous religious (and sexual) practices taking place in this house. Among the lodgers was a Christian Armenian servant working for a Turkish merchant, who allegedly forced his young employee to dress like a Muslim and follow Muslim customs, including eating meat on days prohibited to Christians. In addition, there were rumours that the unmarried Paolina had sexual relations with her Muslim guests, and that

\footnotetext{
* In transcriptions from early modern sources, I have modernized spelling and expanded abbreviations. All translations are my own. The Venetian calendar began on 1 March. I have adapted more veneto dates to the modern style. The research for this article was funded in part by the European Union's Horizon 2020 research and innovation programme under the Marie Skłodowska-Curie grant agreement No. 702296. I would also like to thank Claire Judde de Larivière, Paul Nelles, Massimo Rospocher and Saundra Weddle for their feedback and suggestions on earlier drafts.
} 
she procured Christian prostitutes for the men in her house. Paolina denied allegations of sexual misconduct, but acknowledged that her lodgers followed their own religious rites, especially in relation to food: the 'Greeks follow Greek customs, and the Turks, Turkish ones, so that the Turks eat meat on Friday and the Greeks on Saturday'. ${ }^{1}$

At the same time as these foreigners created their own social space within the lodging house in which they could, apparently, preserve their particular customs, the case also makes clear how Paolina's home was a permeable environment with close relations to the surrounding neighbourhood. As well as the comings and goings of Christian, Greek and Ottoman lodgers, a Slavic maid cleaned the rooms, while visitors to the house included Greek women from the neighbourhood. A Cypriot and another Armenian lived in the same courtyard, and nearby was another house lodging eastern Mediterranean travellers. Nor was Paolina's house exceptional. Rather, it was one of many establishments in which ordinary Venetians - both native and foreign-born - shared space with and provided temporary homes to migrants and visitors.

By the sixteenth century, Venice was among the most cosmopolitan cities in Europe and the Mediterranean region. As the capital of a vast multilingual and multifaith empire, it was well established as a cultural crossroads and a destination (at least a temporary one) for streams of people on the move. As well as merchants, these included artisans, soldiers, sailors, pilgrims, diplomats, beggars, sex workers and many more. Hundreds of people came and went from the city every day, to and from every direction, and for an infinite variety of reasons. Some intended to settle for good, including refugees who could not return to their homes. Others planned to visit for only a couple of days, while many more meant to stay for a few months or years, until the work ran out or a better opportunity arose elsewhere. As a result of this intense mobility, negotiating differences of language, religion and customs, and finding ways to co-exist in close quarters while limiting outright conflict, were part of the quotidian quality of city life.

Although the highly mobile nature of early modern Europe, and especially of the Mediterranean region, is now broadly acknowledged, there is still much to know about what this meant in the daily lived experience both of people on the move and of the communities that they passed through or settled in. ${ }^{2}$ This is true even in the case of Venice, despite

1 'Grechi fanno alla greca, e turchi alla turchescha, in modo che i turchi mangiano carne il venerdì e i grechi il sabbato.' Archivio di Stato, Venice (ASV), Sant'Uffizio (SU), b. 47, fasc. 2 , fol. 15v. The Inquisition investigated several denunciations of Paolina between 1581 and 1588 , but never seem to have punished her.

${ }^{2}$ For the bigger picture, see C. Moatti and W. Kaiser, 'Mobilità umana e circolazione culturale nel Mediterraneo dall'età classica all'età moderna', in P. Corti and M. Sanfilippo (eds.), Storia d'Italia. Annali 24: Migrazioni (Turin, 2009), 5-20; J. Lucassen and L. Lucassen, 'The mobility transition revisited, 1500-1900: what the case of Europe can offer to global history', Journal of Global History, 4 (2009), 347-77. 
important studies which have examined individual foreign communities in the city. Historians have focused particularly on the characteristic 'spatial politics' adopted by the Venetian authorities in dealing with the presence of foreigners, exemplified by the establishment of the German trading house or Fondaco dei Tedeschi in the early thirteenth century or the Jewish Ghetto in 1516. This approach has contributed to a vision of the city as comprised of small islands of otherness in a larger sea of 'native' Venetians. ${ }^{3}$ As elsewhere, research on Venice also has concentrated largely on those who came to settle, meaning that more temporary forms of mobility tend to disappear from the picture, except in the case of prominent visitors such as merchants. As such, many of the ephemeral encounters, interactions and exchanges between people on the move and urban inhabitants, that made up day-to-day life in a cosmopolitan city, remain obscured. ${ }^{4}$

A new perspective opens up when we shift our attention from particular 'immigrant' groups to broader, and overlapping, categories and practices of mobility and the infrastructures that facilitated or impeded them, an approach suggested by the so-called 'mobilities paradigm' emerging largely from the social sciences. ${ }^{5}$ As studies of great capitals like eighteenth-century Paris have shown, the rapid urbanization of the premodern period necessitated various kinds of 'stop-gap accommodation' to receive newcomers, and generated significant economies of hospitality. Studying these spaces of arrival for migrants and visitors brings into focus the complex and multilayered impact of mobility on the development of Europe's urban centres. ${ }^{6}$ As one of the largest and most multicultural cities in early modern Europe, Venice was one of the first to have to find ways to

${ }^{3}$ For an overview of this extensive literature, see B. Ravid, 'Venice and its minorities', in E.R. Dursteler (ed.), A Companion to Venetian History, 1400-1797 (Leiden and Boston, MA, 2013), 449-85. A few important recent works have argued for the more fluid nature of identities across the Venetian empire. See in particular E.N. Rothman, Brokering Empire: Trans-Imperial Subjects between Venice and Istanbul (Ithaca and London, 2012); G. Minchella, Frontiere aperte: Musulmani, ebrei e cristiani nella Repubblica di Venezia (Rome, 2014). In this article, according to the usage current at the time, I consider foreigners to be anyone coming from outside the city of Venice.

${ }^{4}$ On the often neglected importance of temporary migration in urban history, see B. De Munck and A. Winter, 'Regulating migration in early modern cities: an introduction', in B. De Munck and A. Winter (eds.), Gated Communities? Regulating Migration in Early Modern Cities (Farnham, 2012), 1-22.

${ }^{5}$ For an overview, see J. Urry, Mobilities (Cambridge, 2007); see also T. Cresswell, 'Towards a politics of mobility', Environment and Planning D: Society and Space, 28 (2010), 17-31.

${ }^{6}$ See, in particular, C. Regnard, 'Stopgap territories. Inns, hotels and boarding houses in Marseille at the beginning of the 1870s', Quaderni storici, 151 (2016), 197-220; and, in the same journal issue, E. Canepari and C. Regnard, 'Premessa: Abitare la città. Residenza e precarietà in età moderna e contemporanea', 103-12. On other important centres in later periods, see E. Canepari, 'Cohabitations, household structures and gender identities in seventeenth-century Rome', Villa I Tatti Studies, 17 (2014), 131-54; B. Capp, 'The poet and the bawdy court: Michael Drayton and the lodging-house world in early Stuart London', The Seventeenth Century, 11 (1995), 27-37; D. Roche (ed.), La ville promise. Mobilités et accueil à Paris fin xviie-début xixe siècle (Paris, 2000); S. Hamadeh, 'Invisible city: Istanbul's migrants and the politics of space', Eighteenth-Century Studies, 50 (2017), 173-93; A.C. Kay, 
cope with mobility on a grand scale, an issue made all the more complex by the delicate nature, and finite extent, of its lagoon environment. The sixteenth century in particular was a crucial moment in the long-term development of the city's sophisticated system of commercial hospitality, that would also underpin its transformation into a great tourist mecca. ${ }^{7}$

This article argues that lodging houses (known in Venice as albergarie or camere locande) provide us with an especially useful key to understanding the everyday impact of mobility in an early modern cosmopolis, and in the experience of its inhabitants and visitors. It unearths an 'underground economy' of accommodation that has, on the whole, remained invisible, because of its largely ad hoc, informal and quasi-domestic character. ${ }^{8}$ Lodging houses formed an integral part of the emerging infrastructure of hospitality that was critical to the functioning of Venice as an economic, cultural and political centre. A close look at these spaces from a variety of angles throws into relief their importance to the many Venetian inhabitants who found a niche renting beds or rooms to new arrivals, as well as to the people who stayed in them. Here, newcomers found not only accommodation and food, but also useful information, access to social and professional networks, companionship, conversation, interesting ideas and novel experiences, all of which could have a profound effect on their onward journeys within or away from the city.

\section{Housekeepers and the lodging sector}

In the thirteenth and fourteenth centuries, a commercial hospitality sector had emerged in Venice, in which the largest and most evident structures were the inns or osterie. Closely overseen by the government, these were clustered around the two central nodes of political, religious and economic life: Piazza San Marco and the Rialto market district. ${ }^{9}$ While the authorities supervised the inns partly in order to keep an eye on those who passed through them, they also designated a number of other spaces to house and monitor particular foreign groups, most famously the Fondaco dei Tedeschi at Rialto, where merchants from the Holy Roman

\footnotetext{
'A little enterprise of her own: lodging-house keeping and the accommodation business in nineteenth-century London', London Journal, 28 (2003), 41-53.

7 R.C. Davis and G.R. Marvin, Venice, the Tourist Maze: A Cultural Critique of the World's Most Touristed City (Berkeley, 2004).

${ }^{8}$ Cf. D. Roche, 'Logeurs et hôteliers', in Roche (ed.), La ville promise, 295, on the 'economie souteraine' of lodging in Paris. Although very little studied, there is some mention of Venetian albergarie in the important survey article: M. Costantini, 'Le strutture dell'ospitalità', in A. Tenenti and U. Tucci (eds.), Storia di Venezia dalle origini alla caduta della Serenissima, vol. V: Il Rinascimento: società ed economia (Rome, 1996), 881-911; and in M. Chojnacka, Working Women of Early Modern Venice (Baltimore and London, 2001), 97100.

${ }^{9}$ On the 20 or so osterie, see Costantini, 'Le strutture', which also discusses the case di comunità: inns meant to host eminent visitors from particular communities in the Venetian state.
} 


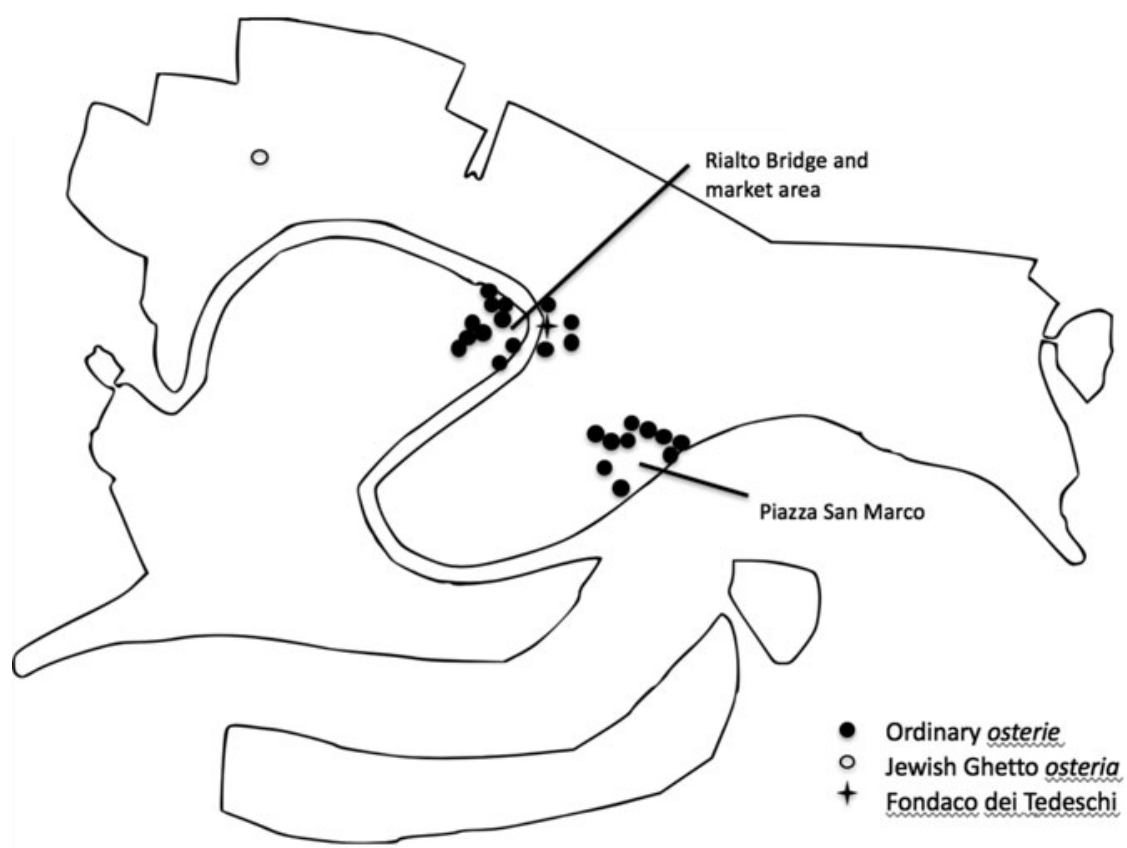

Figure 1: Osterie active during the sixteenth century in Venice.

Empire were required to lodge (Figure 1 ).${ }^{10}$ The sixteenth century saw a new impetus to separate and segregate non-Catholics in particular, expressed in the creation of the Jewish Ghetto (with its own inn to receive Jewish travellers) and the Fondaco dei Turchi to accommodate Muslim merchants. ${ }^{11}$ However, these establishments were not sufficient to host the tides of people who made their way to the city (nor did every foreign arrival stay where they were meant to), and other accommodation providers soon appeared to fill the gaps.

${ }^{10}$ For a recent overview, see P. Braunstein, Les allemands à Venise (1380-1520) (Rome, 2016). On the spread of the Fondaco model more generally, see O. Constable, Housing the Stranger in the Mediterranean World: Lodging, Trade, and Travel in Late Antiquity and the Middle Ages (Cambridge, 2003; repr. 2006), esp. ch. 9.

11 B. Ravid, 'The religious, economic and social background and context of the establishment of the ghetti of Venice', in G. Cozzi (ed.), Gli ebrei e Venezia, secoli xiv-xvii (Milan, 1987), 211-60; M.P. Pedani, Venezia, porta d'oriente (Bologna, 2010), ch. 8; E. Concina, Fondaci. Architettura, arte e mercatura tra Levante, Venezia e Alemagna (Venice, 1997), 220-40. Muslim merchants were meant to lodge in a former inn at Rialto from the late 1570s, before the institution of the Fondaco dei Turchi in 1621 although, as the aforementioned example of Paolina Briani's house shows, not all did. From 1528, because of fears of the spread of Protestantism, the government also sought to limit German merchants to staying, if not in the Fondaco dei Tedeschi, then in a couple of inns and lodging houses run by fellow northerners located nearby. Braunstein, Les allemands, 146. 
Around the middle of the sixteenth century, the Venetian government noted with alarm a very rapid expansion in the provision of private lodgings for people arriving in the city. Unlicensed lodging houses were said to have proliferated from a handful to as many as 5,000 or 6,000 in the preceding decades. ${ }^{12}$ While likely an exaggerated number, this reflects an impression of swift and striking development in this area. The premodern hospitality sector had flexible limits: when demand increased, it was relatively easy for anyone with a spare bed or room to set themselves up as a provider of accommodation to short- or longer-term visitors. Space was a precious commodity in a crowded city, and many sought to profit from it. This was precisely what happened in early modern Venice, where the population grew very rapidly from around 100,000 to nearly 170,000 in the first two-thirds of the sixteenth century, as influxes of migrants and temporary visitors came to fulfil the labour needs of Venice's strong maritime, commercial and industrial sectors, and others sought refuge from Ottoman encroachments in its eastern empire and from outbreaks of epidemic disease, food shortages and war on the Italian mainland..$^{13}$

This confluence of political, economic and demographic circumstances made the politics and practice of hospitality issues of vital concern for Venice's governing bodies, and encouraged new attempts to regulate lodging houses along with other sites of reception. ${ }^{14}$ A series of reforms in this period aimed to make lodging houses more identifiable and thus taxable, but also, increasingly, to use them as points to monitor the movement of foreigners through the urban environment and their interactions with Venetian inhabitants, in order to safeguard public health and security. The authorities sought to impose some order on these transient spaces by limiting the number of tenants and setting minimum periods of tenancy (no less than four months, later lowered to one). Anyone who wished to accommodate foreigners now first had to obtain a licence, for a fee. They were also required to report on arrivals and departures and check that guests carried the correct documentation. Throughout the rest of the period, the government struggled to police this continually expanding sector, and control who could participate in and profit from it. ${ }^{15}$

A surviving register of the Giustizia Nuova, the main magistracy responsible for overseeing this sector until the 1580s, provides a precious

12 Biblioteca del Museo Correr, Venice, manuscript PD 396c-II, vol. II, no. 524. The document, promulgated by the Council of Ten, is undated but is stored with other laws from around the mid-sixteenth century and other references within the text point to this dating.

${ }^{13}$ D. Beltrami, Storia della popolazione di Venezia dalla fine del secolo xvi alla caduta della Repubblica (Padua, 1954), 59.

14 For more details, see R. Salzberg, 'Controlling and documenting migration via urban "spaces of arrival" in early modern Venice', in H. Greefs and A. Winter (eds.), The Regulation of Migration and the Materiality of Identification in European Cities, 1500-2000 (London and New York, forthcoming 2018).

15 See the laws collected in ASV, Compilazione delle leggi (CL), b. 12, fasc. 'albergarie'. 


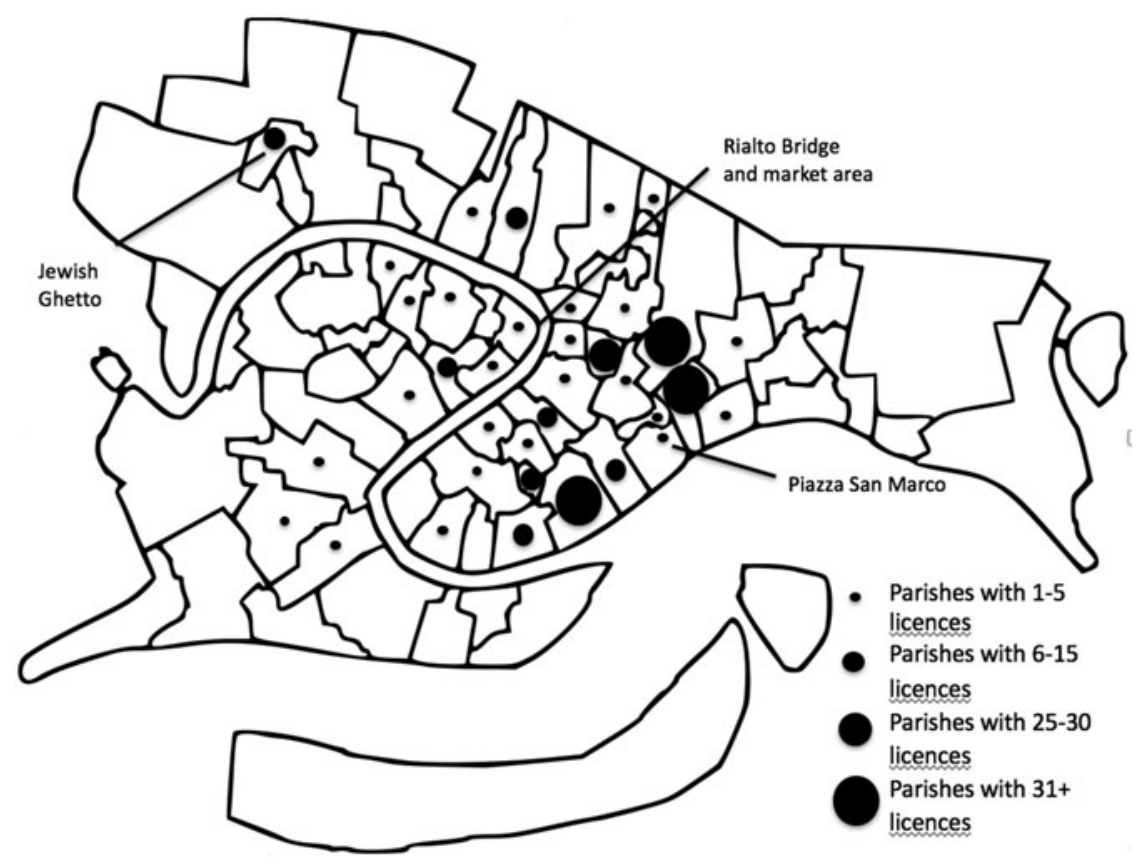

Figure 2: Venice parish map with location of albergarie licences, 1530-2.

opportunity to assess the most visible side of the expanding economy of lodging. Covering a two-year period (1530-2) when Venice was at the apex of its ability to attract migrants and visitors, this valuable source allows us to identify around 200 individual licensed houses operating just in this brief window of time. ${ }^{16}$ These establishments must have covered a wide spectrum of size, quality and permanency, ranging from large houses renting out numerous rooms or beds to small dwellings accommodating just one lodger, and from more temporary, informal enterprises to more enduring ones. They were clustered particularly to the west of the piazza around the important commercial street of the Frezzeria and to the east in the area close to the waterfront Riva degli Schiavoni (so called because high numbers of Slavic migrants lived in the vicinity) where many ships docked (Figure 2). In a few streets and courtyards, lodging houses appear to have been lined up one after another. Here, then, a shadow geography of hospitality becomes more evident, forming a larger second ring around the central zone which was meant to be the monopoly of the inns. Moreover,

16 ASV, Giustizia Nuova (GN), b. 5, reg. 12. 272 permissions for housekeepers to accept tenants were granted between 14 Feb. 1530 and 6 Mar. 1532. 30 or so housekeepers obtained two or more licences to lodge different groups of guests, however, because of the nonuniform recording of names, it is not always possible to confirm with certainty when the same individual appears more than once. 
this particular source almost certainly reveals merely the most obvious tip of a lodging iceberg. ${ }^{17}$

By the mid-sixteenth century, many Venetian residents perceived that providing hospitality, especially on a short-term, high-turnover basis, could be a lucrative enterprise. So concluded two characters in Anton Francesco Doni's 1559 play, Lo stufaiolo (The Bathhousekeeper), set in Venice. Believing themselves to have inherited their master's house after his death, the servants Caterina and Bigio immediately discuss setting up as lodging housekeepers, dreaming of all the money to be made. ${ }^{18}$ And indeed, it is precisely in this period that we see a clearer category of commercial lodging house emerging, increasingly identified as camere locande (rented rooms). Although, little by little, the lodging housekeeper would become a more distinct occupational group, at this time it was less often a specialized profession than a side-line. Venice had no guild of albergatori, meaning that a wide variety of people could participate in this activity and that there is no way to compile a complete census of them. ${ }^{19}$ Nonetheless, some common characteristics emerge.

Many of the people providing lodging had a primary profession as artisans or shopkeepers. Those seeking licences in 1530-2 included tailors, barbers, painters, cobblers, second-hand dealers. Others worked in service professions that brought them into contact with foreigners, such as the barcarolo (boatman) who hosted a doctor from Cremona and the ligador (merchandise packer) at the Fondaco dei Tedeschi who accommodated some Germans in $1531 .^{20}$ Commercial brokers or sensali commonly profited from their association with foreign merchants to offer lodging as well, even though this was technically prohibited. ${ }^{21}$ More educated professionals also rented rooms in their homes, as did the lawyer (solicitador di cause in palazzo) Camillo de' Filimberti in the $1560 \mathrm{~s}^{22}$

As was the case in other European cities where significant lodging sectors developed in later centuries, however, this was a markedly female business: an economic space that women could occupy, not monopolized

${ }^{17}$ In theory, only certain categories of more favoured arrivals (including diplomats, clergy, scholars and military officers in the employ of the Republic) were to be given permission to move into private lodgings. Nonetheless, there were continuous complaints that many others received permits, or simply found accommodation without permission. What were probably the largest categories of mobile people moving through Venice, galley sailors and artisans seeking work, could lodge where they liked, and so left few documentary traces. ASV/CL, b. 299, 'osterie' (27 Sep. 1505).

18 A.F. Doni, Lo stufaiolo (Lucca, 1861), Act 5, Scene 2.

${ }^{19}$ In contrast, innkeepers (osti) were incorporated in a guild from the fourteenth century.

${ }^{20}$ ASV/GN, b. 5, reg. 12, fols. $159 \mathrm{v}, 203 \mathrm{v}$.

${ }^{21}$ Rothman, Brokering Empire, esp. ch. 2; E. Burke, 'Francesco di Demetri Litino, the Inquisition and the Fondaco dei Turchi', Thesaurismata, 36 (2006), 79-96.

${ }^{22}$ L. Calò, Giulio Gherlandi, 'heretico ostinatissimo'. Un predicatore eterodosso del Cinquecento tra il Veneto e la Moravia (Venice, 1996), 62, 179. Cf. O. Ronchi, 'Alloggi di scolari a Padova nei secoli xiii-xviii', Bollettino del Museo Civico di Padova, 56 (1967), 293-319, on Padua, where priests and professors, among them Galileo Galilei, were among those who rented rooms to scholars. 
by a guild nor requiring specialized training or equipment. ${ }^{23}$ In Venice, we find women who were artisans or retailers in their own right (including a furrier, a coal seller and a glove-maker) accepting tenants. ${ }^{24}$ About 60 per cent of the 1530-2 licences were accorded to women, although this likely under-represents the prevalence of female housekeepers. Even when a man was nominally the head of household and might have been the one to seek the required licence and interact with the authorities, it was his wife or female partner who typically dealt with the day-to-day management of lodgers. This division of labour continued to be common. In the 1560s, for instance, the engineer Massimo de' Massimi testified to the Inquisition that his wife Bartolomea ran their lodging house near Piazza San Marco, as he was often out of Venice for work. ${ }^{25}$

Taking lodgers was also a frequent recourse for widows, or wives deserted by their husbands. After the death of her English husband, for example, Diana Palermitana claimed that she had been forced to continue his practice of taking (mostly English) lodgers because she was poor and had no other way to pay her bills. ${ }^{26}$ This career choice could offer newly single women a modicum of security and perhaps respectability, allowing them to remain in the domestic sphere and to combine their work with child-care responsibilities. ${ }^{27}$ However, we also find single (never married) women as lodging housekeepers; particularly - we can surmise - women who had little reputation left to lose. Indeed, there were undoubtedly strong connections between Venice's booming sex industry and the lodging sector, which continually troubled the authorities. ${ }^{28}$

As well as in some cases occupying the margins of respectable society, a good number of those opening their homes to new arrivals were more or less recent migrants themselves. ${ }^{29}$ Even after a 1569 prohibition on foreigners offering lodging, many recent migrants continued to find ways to set themselves up as housekeepers, for example by obtaining a licence in the name of their Venetian-born spouses. ${ }^{30}$ Renting rooms was a source of

${ }^{23}$ Cf., for example, Canepari, 'Cohabitations', 141-2; Kay, 'A little enterprise'.

${ }^{24} \mathrm{ASV} / \mathrm{GN}$, b. 5, reg. 12, fols. 13v (Chiara pelizera), 17v (Menega carbonera), 129r (Franceschina vantera).

25 ASV/SU, b. 21, fasc. 4, fol. 23r.

${ }^{26}$ ASV, Inquisitori di stato, b. 1213 , fasc. 49 (1618). See also the case of a poor widow with three daughters who declared to the authorities in Padua in 1561 that she rented rooms to scholars since 'I don't know how to live if I don't do this.' Cited in Ronchi, 'Alloggi di scolari', 300.

27 Kay, 'A little enterprise'.

${ }^{28}$ See, for example, ASV/GN, b. 1, fol. 109r (1524): courtesans prohibited from accepting paying lodgers who they claimed were merely (non-paying) friends or lovers. See also concerns about Muslim visitors lodging with Christian prostitutes, cited in Concina, Fondaci, 220.

${ }^{29}$ It is very difficult to give precise numbers as licence-seekers were identified in different ways throughout the records: sometimes with a nickname that suggests, but does not confirm, where they were born (for example, furlana, greca, todesco), and only on occasion with a more explicit reference to provenance (for example, da Corfu, da Peschiera).

30 ASV, Consiglio dei dieci, Parte comuni, reg. 29, fol. 64r-v (22 Sep. 1569); ASV, Esecutori contro la bestemmia (ECB), b. 54, fols. 63v-64r (14 Mar. 1589). 
income that was attractive to immigrant women especially, who might lack the skills, capital or connections to make their way in other professions. ${ }^{31}$ As we shall see further below, migrant housekeepers could use their linguistic skills and own experiences of mobility to facilitate interactions with clients who often hailed from the same regions and/or shared their language or faith.

Given the variety of people engaged in the lodging business, and the lack of study of individual housekeepers, it is difficult to generalize about their social or economic position. However, a few further remarks can be made. It would appear that most of them rented, rather than owned, the properties that they managed, as was the case with the majority of Venice's inhabitants. A 1576 petition by lodging housekeepers to the Senate depicts them on the point of economic destitution, particularly because of the need to keep paying high rents and taxes during the period of plague when the flow of people through the city, and consequently their business, temporarily ground to a halt. ${ }^{32}$ Even those who found lodging a profitable venture nonetheless lacked the support of a charitable safety net in difficult times, which membership of a guild might have offered. The government often recognized the neediness of clandestine lodging housekeepers and showed them clemency, as happened in the case of a widow, Barbara, released from prison in 1556 because of her poverty. ${ }^{33}$

The modest economic situation of many of those who offered lodging should not obscure the fact that their work required them to be significant cultural mediators. Like other, better studied occupations such as commercial brokers, they had to negotiate differences of language and custom as well as to liaise between recent foreign arrivals, the local community, and the government, facilitating the passage of mobile people through Venetian society. While expected to report to the authorities on the foreign presence in the city, they also maintained important relationships with those who lived under their roofs. For example, they might assist vulnerable lodgers, who found themselves far away from their normal networks of support, in seeking local medical or spiritual aid. This occurred in 1591, when the 10-year-old Russian slave of a Turkish merchant begged the housekeeper Camilla Dioda to help him flee his master and return to the Christian faith from which he had allegedly been forcibly removed. ${ }^{34}$ As we shall see further below, lodging housekeepers provided not only a place to sleep. They also shared space, broke bread

31 Choinacka, Working Women, 96-7.

32 ASV, Collegio, Suppliche di dentro (CS), f. 6, no. 85. On renting and sub-letting, see P. Fortini Brown, Private Lives in Renaissance Venice (New Haven, 2004), ch. 7.

$33 \mathrm{ASV} / \mathrm{GN}$, b. 5, reg. 13, fol. 4v. See also ASV/ECB, b. 54, fol. 65r (1590): on female housekeepers who, 'being mostly miserable and poor', knew that they would not be punished harshly for failing to report their tenants.

34 ASV/SU, b. 67, fasc. 'Ali Celebin'. The boy also reported that he had learnt some Catholic rituals (prayers and the sign of the cross) in Camilla's house. Disturbed by the boy's plight, Camilla sought the intervention of a neighbour and also reported the case to a local priest. Housekeepers likely also sought medical treatment for lodgers. See, for example, the case 
and exchanged conversation with their tenants, and could play a crucial role in helping newcomers find their feet in the city.

\section{Lodgers and the flows of urban mobility}

Whether forced to leave their homes or moving voluntarily, travelling solo or with a group or family, and whether Venice represented for them a final destination or a place of transit, all kinds of people disembarked in the city. Many quickly made their way to lodging houses, because they were cheaper, quieter, safer, more secluded or more comfortable than the public inns. Turning now to the evidence about who stayed in these houses, we can see more clearly how such enterprises represented a vital resource to a wide range of people coming for a great many different reasons. In particular, this evidence brings to light more transient forms of mobility, as well as the movement of many migrants and visitors, especially from the Italian mainland, who have received less attention from historians interested primarily in the settlement of ethnic or religious minority communities. ${ }^{35}$ This in turn contributes to a richer picture of the numerous fluxes of people, with their various rhythms and speeds, which converged in the Venetian urban environment.

The surviving register of Giustizia Nuova lodging licences is a precious resource for examining the 'upper crust' of people passing through Venice at a moment when the city was at the height of its economic, cultural and political power. The lodgers recorded here appear to have been predominantly shorter-term visitors, staying for a few weeks or months and not intending to settle in the city. ${ }^{36}$ The majority travelled with servants or some kind of entourage and only occasionally with family members. ${ }^{37}$ Thus, although this source highlights the presence of relatively high-profile groups, at the same time it adds new texture and detail to our understanding of their presence in the city and interactions with its inhabitants.

For example, the 1530-2 licences provide valuable evidence about the continuous streams of state-sponsored mobility that underpinned the functioning of the Venetian state. Before the establishment of permanent embassies in the capital, diplomats from across the Venetian empire and beyond routinely found accommodation throughout the parishes of Venice

of a lodger from Friuli, ill and needing medical care, who moved from an inn to the house of Margarita Veronese. ASV/GN, b. 5, reg. 12, fol. 273r.

35 See Ravid, 'Venice'.

${ }^{36}$ However, for a few examples of longer-term stays, see ASV/GN, b. 5, reg. 12, fols. 31v (Genoese cloth merchants, 'già molti anni in questa terra'), 104v (Flemish mercers and jewellers given permission to 'stare e habitare come fanno gli altri che lavorano il suo mestiere in questa terra').

37 Although it can be difficult to distinguish servants from travelling companions, at least 160 of the 272 lodging licences explicitly mentioned the presence of servants of one kind or another (servidor, garzon, ragazzo, cuogo, nena etc.). 
in lodging houses. ${ }^{38}$ So did bureaucrats, such the tax collectors from Vicenza who stayed with a certain 'Paula who sings' in 1531, and highranking military officers, like the captain of infantry Biasio da Cividale, who lodged with some of his men in the home of Elena Bianchi while they waited to board a ship to Crete in the same year. ${ }^{39}$ Others came to serve the state in a cultural capacity, such as the new organist of the Basilica of San Marco, Giulio Segni from Modena, who resided with a knife-maker a few minutes walk east of the great church. ${ }^{40}$

These licences also capture the ebb and flow of other types of migrants and visitors. Although their numbers were diminishing in these years, pilgrims still came to Venice to seek transport for their onward journeys to the Holy Land, stock up on necessary provisions and visit holy sites in the city itself. While some stayed in inns and hostels, others chose lodging houses, such as the large group of Portuguese pilgrims bound for Loreto and Jerusalem who lodged in two houses in the same courtyard in San Moisè in 1530, hosted by the wife of a printer and by a certain Julia from Sebenik in Croatia. ${ }^{41}$ On the other hand, merchants from the eastern Mediterranean were a growing presence at this time. While Levantine Jews were compelled to stay in the Ghetto, Greek and Muslim traders who arrived in these years often chose to lodge in houses run by migrants from the same region, in the area east of Piazza San Marco, near the Greek church and the stretch of docks where they were required to anchor their ships. In March 1532, for instance, two groups of 'Levantine Greeks from the Janina' (now Kanine in Albania) stayed very close to each other in this area, with a Greek woman named Marieta on the narrow street of the Ruga Giuffa, and just around the corner with a Cypriot called Domenico. ${ }^{42}$ Another type of visitor who appears in the lodging licences, and in increasing numbers in the city from this period on, were cultural tourists, attracted to the city for pleasure, education and to buy cultural commodities, such as two groups of French scholars visiting from the

${ }^{38}$ For example, ASV/GN, b. 5, reg. 12, fols. 95r (licence to lodge the Polish orator), $114 \mathrm{v}$ (ambassadors from Friuli), 139r (Brescia), 266r (Kotor in Montenegro). For Ottoman envoys staying in lodging houses as well as inns, see M.P. Pedani, In nome del Gran Signore: Inviati ottomani a Venezia dalla caduta di Costantinopoli alla Guerra di Candia (Venice, 1994).

39 ASV/GN, b. 5, reg. 12, fols. 205v, 292r.

40 Ibid., fols. $242 \mathrm{v}-243 \mathrm{r}$.

41 Ibid., fol. $117 \mathrm{r}$.

42 Ibid., fols. 289v-290v. Marieta also obtained at least two other licences to lodge Ottoman subjects, one group from Vallona in Albania and another also from Kanine (fols. 125r, $283 \mathrm{v})$. On the clustering of eastern Mediterranean migrants in this area, see Pedani, Venezia, 213, 223; E. Burke, The Greeks of Venice, 1498-1600: Immigration, Settlement and Integration (Turnhout, 2017). For examples of Levantine Jews lodging at various houses in the Ghetto, see ASV/GN, b. 5, reg. 12, fols. 43r, 151v, 178v-179r, 187r, 241v. As noted above, there were efforts to segregate Muslim merchants in a proto-Fondaco from the 1570s, although some continued to stay in lodging houses. For more on the factors influencing choice of accommodation, see below. 
University at Padua who found rooms with a female housekeeper in $1532{ }^{43}$

Such instances are significant, as they indicate how, as they spread throughout the city's parishes, even those who did not come primarily to transact business in Venice could still have a notable economic impact, not least on those who provided them with accommodation. The flows of political, commercial and cultural mobility upon which Venice thrived necessitated a broad infrastructure of hospitality that permeated far beyond the inns at Rialto and San Marco, and formally appointed sites like the Fondaco dei Tedeschi, bringing visitors and migrants into close contact with a wide variety of city-dwellers. Moreover, the temporary cohabitations of people on the move with an eclectic range of local housekeepers could lead to interesting instances of cross-cultural encounter and exchange, as we shall see further below.

Other sources identify some more elusive categories of mobile people staying in lodging houses but largely absent from the Giustizia Nuova licences, which record the presence of visitors who were not only mostly elite and temporary but also primarily male. ${ }^{44}$ While women were unlikely to travel for pleasure in this period, for example, many did come to cities like Venice out of necessity, in search of work, and lodging houses could be an important first point of contact. ${ }^{45}$ Given the aforementioned links between the lodging sector and the sex industry, the government worried that such houses posed a threat to unwary female labour migrants, who might be lured into work as prostitutes. ${ }^{46}$ The potential vulnerability of young women in these spaces is suggested in the case of a poor orphan from Ancona called Anzola who found a bed in a camera locanda when she disembarked in the city in the 1570s and ended up accused of stabbing a second-hand goods dealer who followed her onto the roof terrace of the house. ${ }^{47}$ Nonetheless, at important junctures in their lives, single women continued to choose this kind of accommodation, particularly where the presence of older female housekeepers offered some reassurance of safety

43 ASV/GN, b. 5, reg. 12, fols. 284r, 285r. On the significant role of lodging houses (and their keepers) in the language learning of educational travellers in this period, see John Gallagher, Learning Languages in Early Modern England (Oxford, forthcoming 2019), ch. 4. I am grateful to John for sharing a copy of his work with me prior to its publication.

44 Only a few travelled with female family members or servants, and there were no women accommodated by themselves. For reasons of decorum, men who travelled with women were likely to stay in lodging houses rather than the more public and rowdy inns. See, for example, the licence to lodge a male citizen from Trogir in Dalmatia with his wife, his female cousin and her infant daughter, plus a wetnurse. ASV/GN, b. 5, reg. 12, fol. 11v.

${ }^{45}$ Chojnacka, Working Women, ch. 4.

${ }^{46}$ N.-E. Vanzan Marchini (ed.), Le leggi di sanità della Repubblica di Venezia, 4 vols. (Vicenza, 1995-2003), vol. II, 415 (16 Sep. 1539): decree that prostitutes or female pimps who ran lodging houses could not employ young female servants, and that newly arrived servant girls seeking work could only lodge in the houses of reputable women, one of whom was to be designated for each parish. However, for repeated flouting of these rules, see G. Lorenzi, Leggi e memorie venete sulla prostituzione fino alla caduta della Republica, 2 vols. (Venice, 18702), vol. II, 274, 276, 278-9, 281.

47 ASV/CS, filza 6, fasc. 93, cited in Chojnacka, Working Women, 87. 
and respectability. After her husband Domenico went off to fight as a soldier in Corfu, for example, Vittoria, a migrant from Padua, moved into the house run by the widow Magdalena. According to her landlady, Vittoria was still staying there two years later when she was informed about the death of her husband, and remained for some months afterwards living as a (not very sorrowful) widow, until she prepared to marry again, and probably move out, in $1592 .{ }^{48}$

The poorest migrants to Venice also found accommodation in the many cheap, unlicensed lodging houses that clustered in central neighbourhoods such as San Moisè. Despite numerous prohibitions against housing undesirable categories of arrivals such as foreign beggars and vagabonds, and periodic expulsions, these people clearly still provided a ready market to low-end lodging housekeepers. ${ }^{49}$ In 1555, for example, a Donna Hieronima was punished by being chained up in the Rialto market displaying a sign saying that she had accommodated 'low-lifes and beggars' (furfanti et mendicanti). A week later, a maker of scented gloves (muschier) was accused of the same crime. One of his tenants, Zuanne from Parma, had been going around the city begging in a state of scandalous undress. ${ }^{50}$ While regarded as unwelcome by the authorities, such migrants still found places to stay with city-dwellers who perceived a way to profit from their presence.

Between the more luxurious and the more squalid establishments, what was probably the most common type of lodging house in the city but again largely invisible in the lodging licences - was that catering to ordinary working men, mostly hailing from areas with close cultural and political links to Venice (the Italian mainland, Dalmatia and Greece). We glimpse this kind of house in the trial of a certain Donna Chiareta for lodging tenants without permission in 1557. Another widow, perhaps of a blacksmith (fabro), Chiareta then had four lodgers in her house. All young (or at least, seemingly unmarried) men, at least three of them certainly were immigrants, including a cheesemaker from Bassano del Grappa, a lawyer from Udine and a porter in the state flour warehouse whose provenance was not specified. Witnesses testified that these men were long-settled in Venice and that, in Chiareta's house, where each had already lived for several years, they shared meals, exchanged conversation and were visited by friends and compatriots. ${ }^{51}$

As we have seen, then, men and women of almost every social status, profession and background sought accommodation in Venetian houses and a very wide spectrum of establishments catered to their particular

48 Archivio storico del patriarcato, Venice, Examinum matrimoniorum, b. 1 (26 Jun. 1592).

${ }^{49}$ For repeated prohibitions and deportation orders, see Vanzan Marchini (ed.), Le leggi, vol. I, 143-4.

50 ASV, Provveditori alla sanità, b. 730 , fols. 2 v, 3 r.

51 ASV/GN, b. 5, reg. 13, fols. 84v-94r. On the prevalence elsewhere of lodging houses for bachelors, or at least male migrants who had left their families at home, see Canepari, 'Cohabitations'; Hamadeh, 'Invisible city'. 
requirements and desires. As well as bringing to light the sheer range of people coming to, or passing through, the city, the evidence confirms that mobility was not a marginal matter in Venice. Far from being confined to the central inns and other designated spaces for foreigners, many migrants and visitors, bringing with them goods, money, skills, ideas and customs from near and far, disembarked and dispersed rapidly throughout the city's parishes, finding transient homes and sharing space with local inhabitants, as well as with other people on the move.

\section{Sharing space}

Tenants in Venetian lodging houses shared intimate spaces, with housekeepers and servants as well as other visitors to the house. Eating, sleeping, practising devotion and recreation are deeply personal issues closely tied to one's sense of identity, security, belonging and home. Carrying them out in close proximity with relative strangers could trigger encounters, conflicts and exchanges, the more so when one cohabited with people of different provenance, languages, customs and status. ${ }^{52}$ How did mobile people interact in these spaces, with each other and with more settled inhabitants of the city, and what were the consequences of these interactions?

Newcomers selected accommodation purposefully and might move to another house if they were not satisfied with their current arrangement. ${ }^{53}$ How people located and chose a house varied, depending on where they came from, how long they intended to stay and what they planned to do. Unlike the inns, lodging houses were not yet normally identified by prominent signs, and must have been more commonly found by word of mouth. In 1556, for instance, a scholar from Udine arriving in the city asked around until he located a suitable house next to a wine shop close to Rialto. ${ }^{54}$ Some newcomers were led to houses by porters and touts who approached them as they disembarked from boats. ${ }^{55}$ In other cases, professional connections seem to have led to the choice of accommodation, as in the case of two groups of foreign jewellers who came to practise their art and elected to stay in the house of Piero romano, a jeweller living close to Piazza San Marco, in the early 1530s. ${ }^{56}$

Clearly, for many of those who first set foot in the city, in Venice as elsewhere, the 'choice of lodgings - albeit temporary - was not left to chance but was in response to individual or group strategies aimed at

52 For a sociological approach to these questions, see P. Boccagni, Migration and the Search for Home (London, 2017). Cf. B. Arbel, 'Daily life on board Venetian ships: the evidence of Renaissance travelogues and diaries', in G. Ortalli and A. Sopracasa (eds.), Rapporti mediterranei, pratiche documentarie, presenze veneziane: Le reti economiche e culturali (xiv - xvi secolo) (Venice, 2017), 183-220, on the even more intense co-existence aboard ships.

53 See, for example, ASV / GN, b. 5, reg. 12, fols. 13v, 47r, 55v, 98v, 206r.

54 ASV, Podestà di Murano, b. 61 (5 Mar. 1556).

55 ASV/GN, b. 5, reg. 12, fol. 262v.

56 Ibid., fols. 30r, $152 \mathrm{r}$. 
ending up in familiar territory'. ${ }^{57}$ This often meant electing to stay with compatriots and/or co-religionists. Indeed, the 1530-2 lodging licences suggest how many newcomers clearly preferred to dwell with those who were similar to them. ${ }^{58}$ The possibility to speak one's own language, practise personal religious customs, eat familiar food and share news from home were powerful attractions for migrants and visitors, particularly in these most intimate spaces of (temporary) domesticity.

Nonetheless, in the teeming streets of Venice, it was impossible for different groups of people, and all of the streams of mobility that they represented, to remain entirely separate from each other, and from the inhabitants of the city. This is clear if we look more closely at the nature of these houses as material and social spaces. For example, it is likely that most were hard to distinguish from the other small, densely packed dwellings that lined the city's small courtyards and narrow streets. Although such structures typically had private entrances, windows and the general proximity between one residence and another 'guarantee[d] that no act went unobserved'. Courtyards, like the one on which Paolina Briani's home and many other lodging houses were situated, operated 'like an open-air portego, with the double row of paired doorways ensuring social contact among the neighbours' ${ }^{59}$ Even large lodging houses like the Greek broker Francesco Litino's, where the doors were locked to protect the valuable merchandise of the eastern merchants who stayed there, were porous spaces. Turkish servants interacted from the balconies with acquaintances who passed over the nearby bridge. Visitors to the house, such as a local artisan who came to do a job for the housekeeper's son, mingled with Muslim lodgers, witnessing their religious rituals and even borrowing money from them. Comings and goings were watched by neighbours, who reported to the Inquisition that an escaped slave was hiding out in Litino's house, planning to convert to Islam and flee to Constantinople. ${ }^{60}$ In other words, in contrast to more enclosed spaces like the Jewish Ghetto or the Fondaco dei Turchi which, theoretically at least, were designed to hide foreign communities away from the rest of the Venetian population behind high walls and gates closed at night, with all but a few doors and windows sealed up, the city's lodging houses provided significant opportunities for migrants and visitors to interact with - or at least be observed by - the settled community. ${ }^{61}$

Inside these houses, too, lodgers were likely to share space. The house where the Nuremberg artist Albrecht Dürer likely stayed during a sojourn

57 Regnard, 'Stopgap territories', 211.

58 For example, see n. 42, above.

59 Fortini Brown, Private Lives, 202.

60 ASV/SU, b. 35, fasc. 12.

61 On the Fondaco and Ghetto, see above, n. 11. However, see B. Ravid, 'Curfew time in the Ghetto of Venice', in Studies on the Jews of Venice, 1382-1797 (Aldershot, 2003), 237-75, showing that even the supposedly fortress-like Jewish Ghetto was somewhat permeable to traffic in and out. 
in Venice in 1506-7, for example, had at least four bedrooms furnished with eight beds as well as spaces for communal dining and three shared lavatories. ${ }^{62}$ In less luxurious houses, tenants likely slept in even closer quarters, with more beds crammed into each room. ${ }^{63}$ The most affluent lodgers might be able to afford a more comfortable and private space, but not always. The French nobleman and writer Montaigne, who stayed only a week in Venice in 1581, complained that his lodging house was 'too public, and in bad condition,' whereas he praised his accommodation in the Tuscan city of Lucca where 'my room was secluded; I lacked nothing; there was no hindrance or disturbance at all...I slept and studied as I pleased. ${ }^{64}$

Even the most well-to-do lodgers could not avoid interaction with people of different status, age and background, including the housekeeper, their family and servants. Especially when away from home, servants frequently slept in the same room as their masters, as well as preparing meals for them, even when they followed different religious rites. ${ }^{65}$ Whether employed by the housekeeper or one of the tenants, servants themselves were often widely travelled migrants, and could also play important roles as cultural and linguistic intermediaries. Francesco Litino, for example, could not speak Turkish, but communicated with one merchant lodger in a Slavic language, with the aid of an Ottoman servant who spoke some Italian. ${ }^{66}$ The Inquisition trial concerning Litino's house also reveals how guests and their servants, many of them Muslim, mingled with the housekeeper's wife and children, as when a Turkish tenant offered some of his food to Litino's four-year-old daughter (her mother forbade her to eat it, fearing that the unfamiliar dish might contravene fasting restrictions, and gave it to the cat instead) ${ }^{67}$

As this instance shows, the preparation and consumption of food could lead to especially sensitive moments of encounter in lodging houses, which often exposed points of tension between different cultural or religious customs. ${ }^{68}$ Although the Venetian government imposed rules about how or whether hosts could offer food and drink to their guests, it

62 Braunstein, Les allemands, 866. On lodging house furnishings, which might also expose tenants to innovative forms of material culture, see D. Roche, 'Dépenses, consommations et sociabilités', in Roche (ed.), La ville promise, 325-52; J. Styles, 'Lodging at the Old Bailey: lodgings and their furnishing in eighteenth-century London', in J. Styles and A. Vickery (eds.), Gender, Taste and Material Culture in Britain and North America, 1700-1830 (London and New Haven, 2006), 61-80.

${ }^{63}$ Cf. Roche, 'Dépenses', 336-7. In some cases, lodgers had to provide their own beds, as rooms were unfurnished. For example, ASV/GN, b. 5, reg. 12, fol. 153r-v.

${ }^{64}$ M. de Montaigne, 'Travel journal', in The Complete Works, trans. D.M. Frame (New York, 2003), 1238-9.

65 See, for example, ASV/SU, b. 35, fasc. 12.

66 Ibid., fol. 16v.

${ }^{67} \mathrm{Ibid}$, fol. 13r. See also above, n. 34: the Russian servant boy who appealed to a lodging housekeeper for help to flee his master. For the case of a converted Muslim teaching the children in the house where he lodged Turkish, see Minchella, Frontiere aperte, 27.

${ }^{68}$ Cf. E.R. Dursteler, 'Infidel foods: food and identity in early modern Ottoman travel literature', Journal of Ottoman Studies, 39 (2012), 143-60. 
is clear that a variety of arrangements were possible, even within the same house. ${ }^{69}$ The Scottish traveller Fynes Moryson, who visited Venice in the 1590s, noted that in Italian lodging houses it was the custom for all to:

eate at a common table, but each man hath his owne meat provided, the Hostesse dressing it, and serving each man with his owne napkin, glasse, forke, spoone, knife, and...glasse of wine, which after meate are severally and neately laid up by the Hostesse. And at the table, perhaps one man hath a hen, another a piece of flesh, the third potched egges, and each man severall meat after his diet. ${ }^{70}$

Foreign-born lodging housekeepers hosting compatriots might provide them with familiar dishes from home. The German albergatore Corrado, for instance, also catered for large wedding banquets 'in the German style' in his lodging house near the Fondaco dei Tedeschi. ${ }^{71}$ Elsewhere, lodgers might prepare their own food, especially if they needed to follow a particular diet for religious reasons (Paolina Briani noted that the Turkish and Greek men in her house cooked for themselves and did so 'better than women'). ${ }^{72}$ In a lodging house in the Ghetto in 1531, Levantine Jewish merchants had their servants cook for them on the fireplace in their room. ${ }^{73}$ Tenants who prepared their own meals could source the products they desired from local providers, or if they had their food made by the housekeeper might give instructions about how dishes were to be cooked. This led to numerous opportunities for the transmission of information about different ingredients, dishes and cooking methods in both directions. ${ }^{74}$

These kinds of intimate, quotidian exchanges between visitors and inhabitants in the city, centred around meals and other sociable occasions, might in turn foster interactions about a range of serious matters, such as faith and politics, and lead to the confrontation, and cross-pollination, of different ideas and practices. In the 1570s, for instance, Prospero, an immigrant from Bologna long settled in Venice who supplemented his income as a hat pedlar by renting rooms to foreigners, was reported to have picked up heterodox religious ideas from his tenants, among them a Florentine banished for heresy and some English Protestants

${ }^{69}$ One 1531 licence, for example, specified that the guest could agree to pay just for the room, by the month or year ('spese al mese, al anno'), or a dozzina (with food and wine included in the cost). ASV/GN, b. 5, reg. 12, fol. 176v.

${ }^{70}$ F. Moryson, An Itinerary...Containing his Ten Yeeres Travel..., 2 vols. (London, 1617), vol. II, 116.

71 ASV/GN, b. 5, reg. 13, fol. 56r: permission to host a wedding feast 'juxta il consueto di loro tedeschi'.

${ }^{72}$ ASV/SU, b. 47, fasc. 2, fol. 18r.

73 ASV/GN, b. 5, reg. 12, fol. 153r-v. Cf. also ASV/SU, b. 35, fasc. 12, fol. 14r, on Turkish merchants doing the same.

${ }^{74}$ Cf. H. Diner, 'Road food: Jewish peddlers during the great Jewish migration and their new world customers', Quaderni storici, 151 (2016), 23-49. Such exchanges surely contributed to the 'melting pot' nature of Venetian cuisine, on which see F. Faugeron, Nourrir la ville. Ravitaillement, marchés et métiers de l'alimentation à Venise dans les derniers siècles du Moyen Âge (Rome, 2014), 763. 
whom Prospero also witnessed eating meat on prohibited days. ${ }^{75}$ The engineer Massimo de' Massimi, whose wife took lodgers, blamed one of his foreign guests for the prohibited meat dishes (including veal, goat, sausages and birds cooked in lard) discovered in his house on a 'lean' day. ${ }^{76}$ But prohibited books also were found, which again Massimi claimed had been left by his lodgers, among them a Neapolitan priest, a doctor from Udine, a Veronese engineer and three representatives of the king of Transylvania. Such books likely fed into the heated discussions of reformist religious ideas that regularly took place under Massimi's roof, a space also frequented by locals and friends of the engineer, including a street pedlar, a blacksmith, a painter, an instrument maker and a couple of street singers. ${ }^{77}$

As we can see, Venetian lodging houses were rarely segregated social spaces but constituted nodes and intersection points within and between larger networks of compatriots, co-workers, neighbours and friends. The intermingling of so many people made these spaces into potent sites of encounter, which could have significant ramifications both for those on the move and for the more settled people that they met in the city. Lodging houses were not just anonymous places but could be important spaces of transition. For some, the change was dramatic, as in the cases of newly arrived female migrants lured into prostitution by housekeepers involved in the sex industry, or of Christian servants travelling with Muslim masters encouraged to convert (or reconvert), signalled by their adopting eastern dress, shaving their hair and participating in Muslim rituals. ${ }^{78}$ For most, the transformation was more subtle but still significant, as the new arrival acquired a first orientation in the metropolis, an 'apprenticeship in the ways of the city'. ${ }^{\prime 7}$

\section{Conclusion}

Venice's lodging houses performed a variety of important functions in the lives of the city's inhabitants and visitors. They greatly expanded the range and scope of the city's commercial hospitality provision, opening up accommodation to a wide variety of people whose mobility

${ }^{75}$ ASV/SU, b. 33, fasc. 'Prosperum Capellarium...'.

${ }^{76} \mathrm{Ibid}$., b. 21, fasc. 4, fol. 24r. Massimi testified that he sometimes went with his tenants to help them procure such foods in the local markets.

77 Ibid. See also the example of a post-prandial 'domestic conversation with heterodox implications' between a landlady and her tenants in the 1680s, in F. Barbierato, The Inquisitor in the Hat Shop. Inquisition, Forbidden Books and Unbelief in Early Modern Venice (Farnham, 2012), 55-7; and the landlady Diana Palermitana eating, drinking and discussing the recent Bedmar conspiracy with a French captain and others residing in her house in 1618 in the case cited in n. 26 above. Gambling, as well as the playing of music, singing and dancing, provided other opportunities for sociable interactions in lodging houses. See, for example, Lorenzi, Leggi e memorie, vol. II, 349: 'soni, balli strepitosi et scandalosi cantando canzoni infami et inhoneste contro l'uso del viver modesto' in unlicensed lodgings run by two Flemish women (1651).

${ }^{78}$ See above.

79 Roche, 'Dépenses', 326: the hôtel meublé as 'le lieu d'apprentissage des habitudes citadines'. 
was fundamental to the economic, political and cultural vitality of Venice in this period. As we have seen, they also represented a critical source of income to hundreds, and over time thousands, of local inhabitants who profited from the flux of arrivals landing in the city by providing them with a room, a bed, food and drink. Finally, and more intangibly, lodging houses facilitated mobility and migration by offering newcomers something beyond their basic needs, including access to personal and professional networks, companionship, medical or spiritual aid, entertainment, sometimes a sense of home. But these exchanges were also two-way: in the intimacy of shared living arrangements, inhabitants of the city encountered an expanding world of different customs, food, ideas, languages, goods. Although the great majority remain largely obscured by the ad hoc and informal nature of their activity, housekeepers such as Paolina Briani, Camilla Dioda, Donna Chiareta, Massimo de' Massimi and Francesco Litino start to emerge from the sources as important mediators in moments of cultural, linguistic, religious and sociable interaction. For all of these reasons, the study of these houses serves to enrich our understanding of the nature of everyday life in a highly mobile, multicultural metropolis, and of the cultural and labour networks that coexisted and intertwined there.

One of the aspects that these houses illustrate with particular clarity is the continuous tension between separation and interaction that typified the pre-modern urban experience. As we have seen, although lodging houses provided numerous opportunities for contact with the settled community, encounters were not always harmonious or mutually desired. People who had left their homes behind were likely to seek out housekeepers and fellow tenants with whom they shared things in common, and thus some kind of transitory, but familiar, form of domesticity. From the sixteenth century, this choice was strongly supported by the Venetian authorities who sought, increasingly, to segregate the most 'foreign' foreigners behind high walls and to keep their contact with the local community to a minimum. And yet, throughout this period and beyond, there continued to be frequent occasions for interaction: something enormously difficult to prevent amidst the urban throng, where people were motivated as much by curiosity, and by the desire to learn about - or at least profit from - strangers, as by fear or hostility. ${ }^{80}$ Ultimately, these houses illuminate and embody the efforts of the entire Venetian population, not just its governors but also ordinary inhabitants and temporary visitors, to achieve a delicate balance between interaction and segregation, co-existence and curiosity, profit and exchange.

${ }^{80}$ See, for example, the Muslim merchants who persisted in residing in private lodging houses in other parts of the city even well after the establishment of the Fondaco dei Turchi. Pedani, Venezia, esp. ch. 8. 


\section{Urban History}

Lodging houses, in Venice as elsewhere, were places of transit and transition, not only physical but also cultural, spiritual, professional, social. Whether for a shorter or longer period, they were stopping points in longer itineraries of movement. People stayed in them during brief visits to the city before returning home, or departing for another destination. For others, these houses provided first or temporary dwellings before moving into more settled accommodation, perhaps when one married or set up a workshop, while others stayed for years. It is very rare to be able to follow these itineraries from beginning to end, particularly if people passed through Venice and left for other places. But studying such spaces of transient accommodation is extremely valuable, as they open a rare window into the lives of people passing through, and illuminate how those lives intersected with the stories of other urban-dwellers. They suggest how even those who stayed only temporarily and seemingly left 'without a trace' helped to shape the city and its culture. ${ }^{81}$

${ }^{81}$ Cf. Regnard, 'Stopgap territories', 197. 